\title{
COVID-19 Incidence in Filaraisis Endemic Area: Implication
}

\section{Filariasis Endemik Bölgesinde COVID-19 İnsidansı: Çıkarım}

\author{
(1) Pathum Sookaromdee ${ }^{1}$, (1) Viroj Wiwanitkit ${ }^{2}$ \\ ${ }^{1}$ Private Academic Consultant, Bangkok, Thailand \\ ${ }^{2}$ Department of Community Medicine, Dr DY Patil University, Pune, India
}
Cite this article as: Sookaromdee P, Wiwanitkit V. COVID-19 Incidence in Filaraisis Endemic Area: Implication. Turkiye Parazitol Derg 2022;46(1):82-83

\section{Dear Editor,}

Coronavirus disease-2019 (COVID-19) is still present big global problem. Finding for effective drug against severe acute respiratory syndrome-coronavirus- 2 is ongoing. Of several new proposals, ivermectin is an interesting candidate (1). Clinically, ivermectin is an effective antiparasitic drug. It is also used as a main drug for management of filariasis. In some countries, such as India and Southeast Asian countries, the drug is currently used for filariasis prophylaxis. However, there is still a high incidence of COVID-19 in those countries (2). However, there is still limited data on area specific rate of COVID-19 in the settings where filariasis is endemic and ivermectin is regularly used. Here, the authors discuss on available COVID-19 statistics from an Indochina country, where COVID-19 has been occurred since early 2020.

The local available data from local Ministry of Public Health on COVID-19 (most update data on $14^{\text {th }}$ August 2021) are retrospectively analyzed. The focused area is the northern region of the country, consisting 9 provinces, of which 1 province are classified as an endemic area of filariasis and ivermectin is locally widely used for disease control. The association between incidence of COVID-19 and endemic nature of filariasis is assessed (Table 1). Based on the analysis, the incidence of COVID-19 in the province which is an endemic nature of filariasis is lower than all other provinces which are non-endemic area of filariasis. However, from correlation analysis, there is no significant negative correlation between incidence of COVID-19 and endemic nature of filariasis $(r=-0.209$, $\mathrm{p}=0.589$ ). This is an interesting observation which might imply a possible role of routine ivermectin

\begin{tabular}{|c|c|c|}
\hline $\begin{array}{l}\text { Province } \\
\text { no. }\end{array}$ & $\begin{array}{l}\text { Endemic nature } \\
\text { of filariasis }\end{array}$ & $\begin{array}{l}\text { Incidence of } \\
\text { COVID-19 } \\
\text { (case/100,00 } \\
\text { local population) }\end{array}$ \\
\hline $\begin{array}{l}1 \\
2 \\
3 \\
4 \\
5 \\
6 \\
7 \\
8 \\
9\end{array}$ & $\begin{array}{l}\text { No } \\
\text { No } \\
\text { No } \\
\text { No } \\
\text { No } \\
\text { No } \\
\text { No } \\
\text { Yes } \\
\text { No }\end{array}$ & $\begin{array}{l}2.94 \\
3.51 \\
1.72 \\
49.33 \\
6.95 \\
4.67 \\
3.90 \\
1.41 \\
15.38\end{array}$ \\
\hline \multicolumn{3}{|c|}{ COVID-19: Coronavirus disease-2019 } \\
\hline
\end{tabular}

medication in the filariasis endemic area. This real world data might be an evidence to support further study on role of ivermectin against COVID-19.

Keywords: COVID-19, incidence, filaraisis

Anahtar Kelimeler: COVID-19, insidans, filarezis

\section{*Ethics}

Peer-review: Internally peer-reviewed.

* Authorship Contributions

Surgical and Medical Practices: P.S., V.W., Concept: P.S., V.W., Design: P.S., V.W., Data Collection or Processing: P.S., V.W., Analysis or Interpretation: P.S., V.W., Literature Search: P.S., V.W., Writing: P.S., V.W.

Conflict of Interest: No conflict of interest was declared by the authors.

Financial Disclosure: The authors declared that this study received no financial support. 


\section{REFERENCES}

1. Martin RJ, Robertson AP, Choudhary S. Ivermectin: An Anthelmintic, an Insecticide, and Much More. Trends Parasitol 2021; 37: 48-64.

2. Wiwanitkit V. Ivermectin and COVID-19. Malays J Med Sci 2021; 28: 177. 